\title{
Impacts of salmon lice on mortality, marine migration distance and premature return in sea trout
}

\author{
R. M. Serra-Llinares ${ }^{1,2, *}$, T. Bøhn ${ }^{1}$, Ø. Karlsen1 $^{1}$, R. Nilsen ${ }^{1}$, C. Freitas ${ }^{1,3}$, J. Albretsen ${ }^{1}$, \\ T. Haraldstad ${ }^{4}$, E. B. Thorstad ${ }^{2,5}$, K. M. S. Elvik ${ }^{1}$, P. A. Bjørn ${ }^{1}$ \\ ${ }^{1}$ Institute of Marine Research, Nordnesgaten 50, 5005 Bergen, Norway \\ ${ }^{2}$ UiT Arctic University of Norway, Hansine Hansens veg 18, 9037 Tromsø, Norway \\ ${ }^{3}$ MARE, Marine and Environmental Sciences Center, Madeira Tecnopolo, 9020-105 Funchal, Madeira, Portugal \\ ${ }^{4}$ Norwegian Institute for Water Research, Jon Lilletuns vei 3, 4879 Grimstad, Norway \\ ${ }^{5}$ Norwegian Institute for Nature Research, Høgskoleringen 9, 7034 Trondheim, Norway
}

\begin{abstract}
Brown trout Salmo trutta (L.) is a facultative anadromous species, where a portion of individuals in populations with access to the sea perform migrations to use the richer feeding resources. We investigated the effect of salmon lice Lepeophtheirus salmonis (Krøyer 1837) infestation on the survival and behaviour of wild trout post-smolts (average fork length $=180 \mathrm{~mm}$ ) during their marine migration. Comparisons of the marine migratory behaviour were made between an artificially infested group $(\mathrm{n}=74)$ and a control group $(\mathrm{n}=71)$ in an area with low natural lice infestation pressure. Artificial infestation was estimated to cause $100 \%$ prevalence and a mean

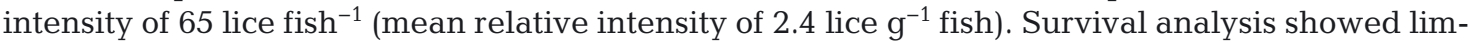
ited statistical power but revealed lice-induced mortality, with an estimated hazard ratio of 2.73 (95\% CI $=1.04-7.13)$ compared to the control group, when data from a previous pilot study were included. Surviving individuals in the infested group additionally responded by residing closer to fresh water while at sea, and by prematurely returning to fresh water. On average, infested fish returned to fresh water after only $18 \mathrm{~d}$ at sea, while control fish spent on average $100 \mathrm{~d}$ at sea. The residency in the inner part of the fjord and the premature return to fresh water represent an adaptive behavioural response to survive the infestation, at the probable cost of reduced growth opportunities and compromised future fitness.
\end{abstract}

KEY WORDS: Parasite $\cdot$ Salmon louse $\cdot$ Lepeophtheirus salmonis $\cdot$ Sea trout $\cdot$ Salmo trutta Epizootic · Acoustic telemetry $\cdot$ Mortality $\cdot$ Behaviour $\cdot$ Field experiment

\section{INTRODUCTION}

Migration is a behavioural adaptation that occurs in many animal taxa, enabling individuals to use the best-suited habitat during different life stages and seasons and thereby leading to an increase in individual fitness (Lucas \& Baras 2001, Dingle \& Drake 2007). Partial migration, where only a fraction of the individuals in a population perform migrations, is common, and the balance between the costs and benefits of migration versus residency is thought to

*Corresponding author: rosal@hi.no affect the tendency to migrate (Chapman et al. 2012, Sahashi \& Morita 2018). Salmonid fish spawn in fresh water, but in many of the species, some or all individuals perform migrations to use the richer feeding resources at sea (Gross et al. 1988). Among salmonids, brown trout Salmo trutta is an especially adaptable and flexible species, showing considerable life-history variation within and among populations (Klemetsen et al. 2003), including partial migration. For sea trout (i.e. the anadromous form of brown trout), the advantages of marine migration include

(C) The authors 2020. Open Access under Creative Commons by Attribution Licence. Use, distribution and reproduction are unrestricted. Authors and original publication must be credited. 
the opportunity to access more food, which in turn enhances growth and fecundity. On the other hand, costs may be related to increased predation risk and physiological adjustment to different salinities. The balance of costs and benefits associated with freshwater residency and anadromy may result in different life-history strategies coexisting within the same water system (Jonsson \& Jonsson 1993, 2006, Ferguson 2006). Females tend to adopt the anadromous life-history strategy more than males (Jensen 1968, Pratten \& Shearer 1983, Euzenat et al. 1999, Knutsen et al. 2004), arguably because females have more to gain by increasing body size in terms of higher fecundity (Thorstad et al. 2016). Anthropogenic impacts that reduce the benefits or increase the costs of migration may result in selection against migration, altered life-history traits, reduced body size of individuals and reduced recruitment on a population level (Chapman et al. 2012, Shaw 2016). Studies of how human activities influence animals during their migration are therefore necessary to evaluate consequences for wildlife and biodiversity, both at the individual and population levels, and for the consideration of management measures.

Atlantic salmon Salmo salar (L.) farming has become a large industry, negatively impacting wild salmonids through the occurrence of farmed salmon escapees and the spread of salmon lice Lepeophtheirus salmonis (Krøyer, 1837) and infectious diseases (Taranger et al. 2015, Forseth et al. 2017). Salmon lice are marine parasites that occur naturally on wild salmonids, but salmon farming has increased the number of potential hosts for lice in coastal areas, resulting in an increased infestation pressure on wild salmonids (Heuch \& Mo 2001, Krkošek et al. 2005, Jansen et al. 2012). Sea trout are particularly at risk of experiencing unnaturally high infestation rates as a result of salmon farming, because they typically remain inside the fjords or in coastal waters during their entire marine migration, where most salmon farms are situated.

Salmon lice are ectoparasites that feed on the mucus, skin, muscle and blood of the host fish, causing tissue erosion, osmoregulatory dysfunction, physiological stress, reduced feeding and growth, and increased mortality (Birkeland \& Jakobsen 1997, Bjørn \& Finstad 1997, Dawson 1998, Bjørn et al. 2001, Wells et al. 2006). Salmon lice-induced stress responses and mortality have been documented for both hatchery-reared and wild trout post-smolts under laboratory conditions (Bjørn \& Finstad 1997, 1998, Wells et al. 2006, 2007). Equivalent physiological disturbances, including an integrated stress re- sponse and osmoregulatory disfunctions, have been shown on free-swimming wild trout post-smolts both feeding at sea and prematurely returned to fresh water (Poole et al. 2000, Bjørn et al. 2001). Based on threshold levels shown to induce mortality in laboratory experiments, wild trout carrying potentially deadly lice loads are at times reported in Scotland, Ireland and Norway (Thorstad et al. 2015). However, conclusive results from field experiments are still scarce, and quantitative knowledge on the effects of lice on sea trout in their natural habitat is still limited. Moreover, free-ranging sea trout have the capacity to modify their behaviour to mitigate physiological stress and osmoregulatory dysfunction by prematurely returning to fresh water (Birkeland 1996, Bjørn et al. 2001, Gjelland et al. 2014). This would enable infested fish to regain osmotic balance and increase chance of survival at the probable cost of reduced growth.

Knowledge of the impacts of lice on trout is extensive, but field studies on wild fish that examine population-level effects are still needed (Thorstad et al. 2015). Disentangling the relative role of lice from other factors impacting mortality and fitness of wild fish in nature is challenging. Population-level effects have been quantified in Atlantic salmon in largescale field studies by comparing the survival of fish chemically protected against lice to that of untreated control fish (Gargan et al. 2012, Vollset et al. 2014). Few such studies have been performed on trout (Skaala et al. 2014). These studies have primarily relied on the natural lice infestation level in the study area, which can be highly variable in intensively farmed areas (Serra-Llinares et al. 2014, 2016, Helland et al. 2015). This, in combination with the typically skewed distribution of lice among individuals and the limitations of the prophylactic treatment, make it difficult to deduce the actual infestation level of the experimental fish. An alternative approach is to compare artificially infested fish with non-infested control fish in a farm-free area with low natural lice levels. This approach does not rely on the limited duration of the effect from the prophylactic drug and allows for better control of the levels of lice on the studied fish. Moreover, other secondary effects associated with the treatment are not expected. SerraLlinares et al. (2018) performed a pilot study to test this new method using wild trout post-smolts $(\mathrm{n}=29)$ caught in bag nets shortly after they entered the sea in Sandnesfjord, southern Norway. The authors concluded that, despite limitations in the statistical power rendered by the study, results indicated consistent trends in behavioural differences between 
control and artificially infested fish, suggesting that this shift in method (i.e. using artificial infestation instead of prophylaxis) is a promising novel approach to study impacts from lice on wild free-swimming sea trout. Furthermore, the authors made recommendations on how to increase the power of an eventual follow-up study by (1) increasing the number of individuals tagged, (2) capturing the fish before they enter the sea, to ensure lice-free individuals and (3) expanding the spatial/temporal coverage of the study by use, for instance, of a combination of acoustic telemetry and PIT-tagging. This approach with suggested improvements is followed up in the present study.

Here, we used acoustic telemetry methods to investigate the survival and habitat use of wild trout post-smolts during their marine migration in an area without fish farms and with a low lice infestation pressure. The main aim was to study the impacts of lice on (1) survival, (2) rate and timing of freshwater returns and (3) migration behaviour (in terms of horizontal and depth use of the fjord) by comparing the movements of trout artificially infested with lice and non-infested control fish. Fish in both groups were tagged with acoustic transmitters with depth sensors, enabling recording of both horizontal and vertical fish movements. We hypothesized that (1) liceinfested fish would have a lower survival probability during the first summer at sea compared to control fish; (2) infested fish would return to fresh water earlier than control fish, to regain osmotic balance and de-louse, and (3) infested fish would remain closer to the river and/or swim higher up in the water column, seeking areas/layers with lower salinity.

\section{MATERIALS AND METHODS}

\subsection{Study area}

The study was performed in Sandnesfjord, southern Norway $\left(58.6943^{\circ} \mathrm{N}, 9.1488^{\circ} \mathrm{E}\right.$, Fig. 1) from June to November 2017. There is no salmon farming activity in this fjord, with the nearest active salmon farm located more than $85 \mathrm{~km}$ (sea-way distance) away. Consistently low lice levels were recorded on wild sea trout in Sandnesfjord in the period 2010-2017, with a mean prevalence of $30 \%$ (range 0-98\%) and a mean intensity of 2.5 lice per infested fish (range 1-13) (Karlsen et al. 2018).

The river Storelva flows into Sandnesfjord through a transition area (Songevatn estuary and Næevestadfjord, Fig. 1). The salinity in Sandnesfjord is commonly above $20 \mathrm{psu}$, but the inner part can have a shallow layer of fresh or more brackish water. The transition area is characterized by a strong salinity gradient, increasing from close to 0 psu at the surface to over $30 \mathrm{psu}$ at $50 \mathrm{~m}$ depth. In the upper $3 \mathrm{~m}$, salinity is commonly between 0 and 15 psu, depending on depth, freshwater supply and the hydrodynamic properties of the coastal current (Tjomsland \& Kroglund 2010, Haraldstad et al. 2016).

Atlantic salmon and brown trout use the lowermost $20 \mathrm{~km}$ of the river Storelva as spawning and nursery habitats. The catchment area is $409 \mathrm{~km}^{2}$, with an average annual water discharge of $12 \mathrm{~m}^{3} \mathrm{~s}^{-1}$ measured at the outlet of Lake Lundevatn (Norwegian Water Resources and Energy Directorate ID: 18.4.0, HYDRA database NVE, www.nve.no/hydrologi/hydrologiskedata/historiske-data/data-i-hydra-ii-databasen/).

The local trout population has been monitored for several years. The smolts descend during April and May, with an average annual total length ranging from 150-190 mm (Haraldstad et al. 2017). Sea trout in this system usually spend 2 growth seasons at sea before first returning to the river (Haraldstad \& Güttrup 2015). Annual sea survival from smolt to firsttime spawning ranges from $14-18 \%$, while survival from one spawning to another ranges from $30-60 \%$ (Haraldstad et al. 2018). During a study by Olsen et al. (2006), the age of the sea trout caught in the Skagerrak coastal area, to which the Storelva catchment belongs, between 1998 and 2003 ranged from 2-8 yr, with more females (64\%) than males. The average growth during the first season at sea is about $150 \mathrm{~mm}$ (K. Bleeker pers. comm.).

\subsection{Hydrographic conditions}

Estimates of temperature and salinity to describe the hydrographic properties in Sandnesfjord were retrieved from a hydro-dynamical model simulation using the Regional Ocean Modeling System (ROMS, http://myroms.org; Shchepetkin \& McWilliams 2005, Haidvogel et al. 2008) applying $32 \mathrm{~m} \times 32 \mathrm{~m}$ horizontal resolution. The highest-resolution model was based on a four-fold nested model system where the horizontal grid was refined from $4 \mathrm{~km}$ (the operational forecast model for the Nordic Seas provided by the Norwegian Meteorological Institute and accessible at http://thredds.met.no) to $800 \mathrm{~m}$ (see e.g. Albretsen et al. 2011) and $160 \mathrm{~m}$, all model systems using ROMS. Tides were added to the boundaries of the $800 \mathrm{~m}$ model and interpolated from the global TPXO7.2 (Egbert \& Erofeeva 2002). Applications evaluating and using $160 \mathrm{~m}$ model systems are 


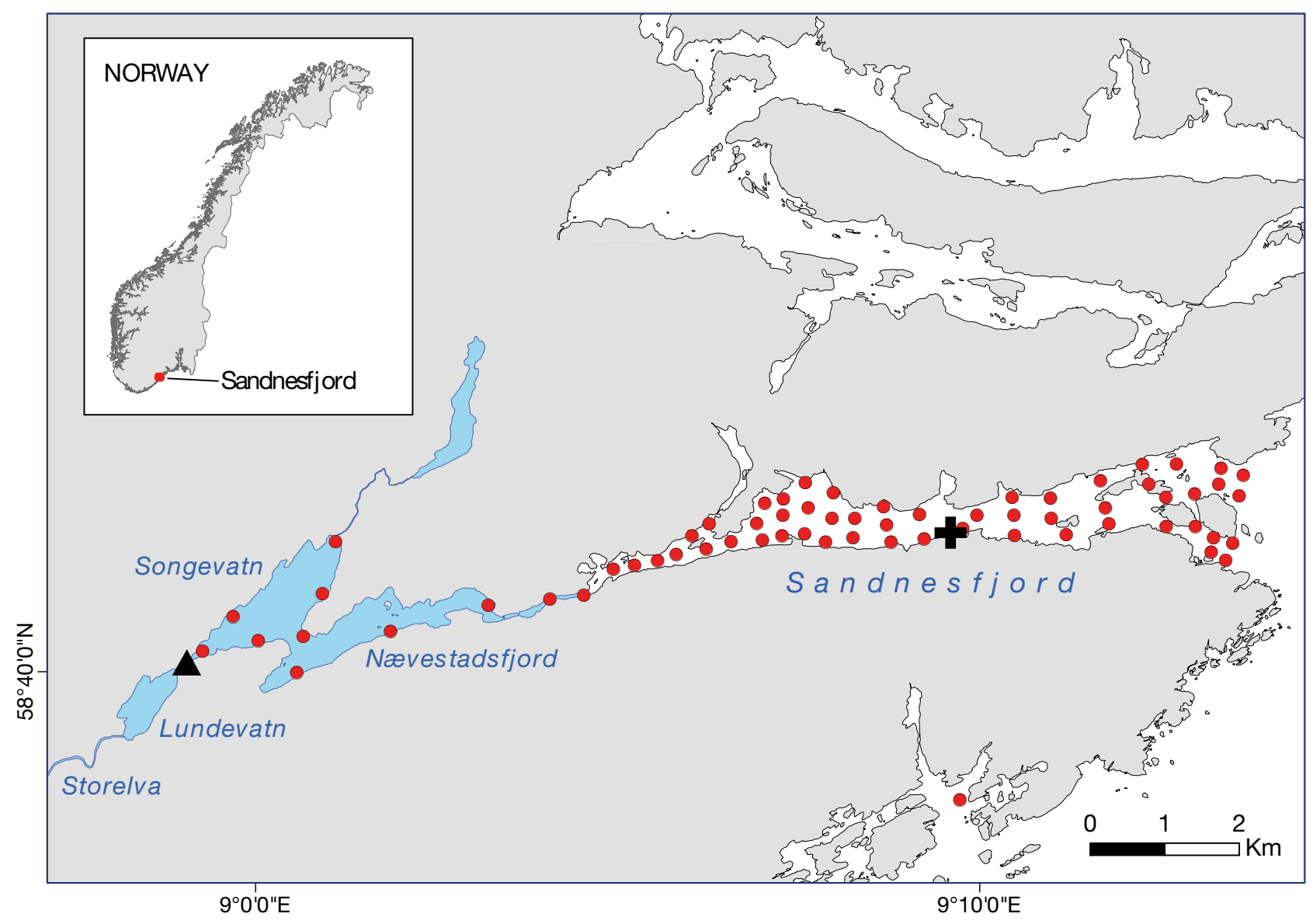

Fig. 1. Study area. Freshwater and transition areas are indicated in blue. The positions for the acoustic receivers (red dots), the fish trap and PIT antenna (black triangle) and the tagging and release location (black cross) are indicated. Note: the farthest receiver, situated approximately $10 \mathrm{~km}$ further south from the outermost receiver in the map, is not shown

described by Espeland et al. (2015) and Huserbråten et al. (2018). The 800, 160 and 32 m models applied high-resolution atmospheric forcing from the nonhydrostatic $2.5 \mathrm{~km}$ AROME MetCoOp regional atmospheric model (Müller et al. 2017) provided by the Norwegian Meteorological Institute and accessible at http://thredds.met.no. The freshwater runoff from Storelva was inputted in the model downstream of the narrow strait of Lagstrømmen (the transition zone denoted with a change from blue to white in Fig. 1), and volume fluxes for all rivers applied in the ROMS models were based on daily measurements from the Norwegian Water Resources and Energy Directorate.

\subsection{Fish tagging and artificial infestation}

Wild trout post-smolts ( $\mathrm{n}=145$; average \pm SD fork length $[\mathrm{FL}]=180 \pm 14 \mathrm{~mm}$; range $155-226 \mathrm{~mm}$ ) were captured in a rotary screw fish trap located in the river mouth (Haraldstad et al. 2017) (Fig. 1) between 18 and 24 May 2017. A rotary screw trap is a sampling gear that takes advantage of flowing water to gently capture and retain downstream migrating fish (Chaput \& Jones 2004). The trap was monitored once or twice a day, depending on capture rates. Captured fish were identified to species, and trout post-smolts were held for a maximum of $48 \mathrm{~h}$ before further handling.

Early-stage lice are highly sensitive to fresh water (Wright et al. 2016). Consequently, the fish were transported by boat in a tank with oxygenated water from the capture site in fresh water to the more saline central fjord prior to tagging and artificial infestation (Fig. 1). First, the fish were moved into a large tank with circulating fjord water, where they could recover and acclimatize for several hours prior to tagging. The fish were then tagged with individually coded acoustic tags with depth sensors produced by 
Thelma Biotel (model ADT-LP-7.3, size: $22 \times 7.3 \mathrm{~mm}$; $1.1 \mathrm{~g}$ in water; depth sensor with $0.2 \mathrm{~m}$ resolution and maximum depth of $51 \mathrm{~m}$, random pulse repetition intervals of 30-90 s; typical battery life of $5 \mathrm{mo}$ ). We anaesthetized the fish by a 3 min immersion in an aqueous solution of benzocaine $(0.1-0.2 \mathrm{ml}$ Benzoak ${ }^{\circledR} \mathrm{l}^{-1}$ ). We then made a small incision on the ventral surface posterior to the pelvic girdle, through which we inserted the acoustic transmitter. Additionally, a PIT tag (23 mm, half duplex, Oregon RFID) was also inserted into the body cavity via the same incision, which was closed using a single silk suture (4/0 Ethicon). After tagging, the fish were randomly assigned to 1 of 2 groups: a control group ( $\mathrm{n}=71$, average \pm SD FL: $181 \pm 14 \mathrm{~mm}$; range $156-220 \mathrm{~mm}$ ) or an infestation group ( $\mathrm{n}=74$, FL: $180 \pm 14 \mathrm{~mm}$; range 155-226 $\mathrm{mm}$ ) and placed into a small net-pen at sea with 2 separated compartments for a recovery period prior to infestation (1-5 d).

Salmon lice copepodids ('LsGulen' family, 30/31 generation in the laboratory) used for artificial infestation were provided by the Institute of Marine Research in Bergen. Approximately 35000 copepodids were collected in the laboratory and sent to the field site in Sandnesfjord. Incubation and quantitative assessment were performed as described by Hamre et al. (2009).

For artificial infestation, all fish in the infested group were placed in an infestation tank $(1 \times 1 \times 0.8 \mathrm{~m}$ fibreglass tank) with circulating fjord water $\left(13^{\circ} \mathrm{C}\right.$, $25 \mathrm{psu}$ ), where they were exposed to approximately 200 copepodids each (i.e. approximately 14800 copepodids were added to the infestation tank). During infestation, water circulation in the tank was stopped and the level was kept at approximately $10 \mathrm{~cm}$ for $30 \mathrm{~min}$. The oxygen content was continuously monitored and regulated during the process. After infestation, the water circulation was re-established in the tanks, where the fish could recover for $12 \mathrm{~h}$ prior to release. To reduce the risk of a potential handling effect impacting our results, the control group received a parallel sham infestation following the same procedure as infested fish in a separate tank. After recovery, all control and infested fish were released in the middle part of the fjord (Fig. 1).

To evaluate the success of the artificial lice infestation, additional 30 post-smolts (FL: $151 \pm 18 \mathrm{~mm}$; range 119-196 $\mathrm{mm}$ ) were used as laboratory reference groups. These were not tagged with acoustic transmitters. Half of them were infested with lice together with the infested fish which were released, as described above. After infestation, both infested and non-infested reference groups were transported by boat in a tank with 2 compartments to the nearby research facilities in Flødevigen, where they were placed in 2 separate tanks (1 per group). After $1 \mathrm{wk}$, their lice levels were recorded.

\subsection{Fish tracking}

The movements of tagged fish were monitored from release (25 May 2017) to the end of the study (29 October 2017) through an array of receivers (Vemco VR2W, which recorded depth, ID and the time when tags were within receiver range) covering the study area both in the fjord and in the transition areas. Range tests indicated an optimal detection range of up to at least $150-200 \mathrm{~m}$ (85\% of the signals were still recorded at this distance). Based on this, we designed a hydrophone array consisting of 66 receivers, of which 55 were placed in sea water and 11 in the transition area (Fig. 1). Migration out of the fjord was monitored by a double array of receivers at the fjord mouth, enabling recording of the movement direction of the fish in this area.

Movements of fish in the river were detected using 2 swim-through PIT-antennas located $150 \mathrm{~m}$ upstream of the river mouth (Haraldstad et al. 2017). At this location, the river is $9 \mathrm{~m}$ wide and $0.9 \mathrm{~m}$ deep. The 2 antennas were installed $2.5 \mathrm{~m}$ apart and wired to 2 remote tuner boards, one for each antenna. The tuner boards were connected to an antenna reader box (TIRIS RI-CTL MB2A; Oregon RFID) and supplied with a $12 \mathrm{~V}$ battery. When a tagged fish passed through the antenna loop, the PIT-tag number, antenna number, date and time were recorded and logged by the reader box.

\subsection{Fish fate assessment}

Individual fish fates were assessed by examination of individual detection plots. Based on their vertical profile and horizontal movements, the fish were classified as:

(1) Dead, when the vertical profile indicated that a tag became stationary. When a diving pattern inconsistent with trout vertical swimming behaviour was observed prior to the tag becoming stationary, the fish was considered to have been eaten by a predator (see Fig. S1 in the Supplement at www.int-res.com/ articles/suppl/m635p151_supp.pdf). The final individual trout record was defined as the last transmitter detection before the tag became stationary or before the predation event. Transmitter detections after this time were removed before further analyses. 
(2) Returned, for fish swimming into the transition area and/or the river (hereafter referred to as fresh water) and remaining there for the rest of the study (i.e. never observed in the main fjord again). Returns before 1 August 2017 were further categorized as early returns, as less than $25 \%$ of first-time migrants return to the river Storelva before that date (Haraldstad \& Güttrup 2015).

(3) Migrated, when last detections occurred in the outer double receiver array in an outwards direction.

(4) Alive at sea, for fish detected alive in the main fjord by 1 October 2017 unless another fate could be assigned after that date. This date was chosen based on the expected life span of the acoustic tags.

(5) Unknown, for fish disappearing inside the study area before the end of the study and before the end of the expected lifetime of the tag.

\subsection{Statistical analyses}

All analyses were performed using the R software version 3.6.0. The receivers recorded 2166380 detections with IDs matching those from tagged trout, and 1601 detections with IDs not corresponding to any tagged fish (which were consequently discarded). A single receiver accumulated $27 \%$ of these unidentified detections. To filter out additional false detections with IDs matching those from fish tags, single detections within a $24 \mathrm{~h}$ window were considered as spurious and discarded. A more restrictive $2 \mathrm{~h}$ filter was applied to the receiver with the most false detections. In total, 1242 spurious detections were removed following this method. Finally, we examined individual vertical and horizontal plots to detect and remove remaining false detections, based on spatial inconsistency.

Fish positions ( $1 \mathrm{~h}$ intervals) were estimated using center-of-activity locations (Simpfendorfer et al. 2002). The center-of-activity location for a given time interval is the mean position of the hydrophones that detected the animal at that time interval, weighted by the number of times the animal was detected at each hydrophone (Simpfendorfer et al. 2002). A mean depth value was also associated with each center-ofactivity position, so that they consisted of a 3D position with latitude, longitude and depth. In addition, we calculated sea-way distance to fresh water (i.e. to the Nævestadfjord outlet) for each center-of-activity position using the 'Spatial Analyst' package from ArcGIS.

Differences in mortality and return to fresh water between control and infested fish were analysed using Cox proportional hazard (Coxph) models, fitted with the 'survival' package (Therneau 2014) in R. For analysis of mortality, the fate/status of each individual fish was set as 1 (died) for fish having a vertical profile indicating mortality, and as 0 (alive) for fish for which mortality could not be identified. Fate time $(t)$ was specified as the number of days between tagging and the observed fate and specified as rightcensored data. By using right-censored data, we could use information on all fish, including fish that migrated out of the study area, which were alive at least until they left. For fish that died by fishing, the fate was set as 0 and the fishing date was used as the fate date. The following Coxph model was used to model the hazard of death at time $t$, as a function of group (control/ infested) and fish length (FL):

$$
h(t)=h_{0}(t) \times \mathrm{e}^{\left(\beta_{1} \text { Group }+\beta_{2} \text { Fish Length }+\beta_{3} \text { Group } \times \text { Fish Length }\right)}
$$

where $h(t)$ is the hazard of the event (death) at time $t$, and $h_{0}(t)$ is the baseline hazard (i.e. the value of the hazard when all exposure variables are equal to 0 ).

Power analysis using the function 'ssizeCT' from the R library 'powerSurvEpi' (Qiu et al. 2012) was used to assess the ability of the fitted Coxph model to detect differences between infested and control fish in this study. We performed scenario testing to estimate the minimum sample size required to detect different hazard ratios (HR) under the premise of 3 fixed parameters: power (i.e. power to detect the magnitude of the hazard ratio as small as that specified by $\mathrm{HR})=0.8$, alpha (i.e. type I error rate) $=0.05$, and $k$ (ratio of participants in each group) $=1$. In other words, we calculated the minimum sample size required to have an $80 \%$ probability of detecting a HR with a confidence of $95 \%$, given the same number of fish in both groups, and using our own data to estimate the remaining parameters such as the expected total number of events in each group.

In anticipation of power analysis indicating insufficient statistical power for the survival analysis, a second Coxph model was specified including data from both the current study $(\mathrm{n}=143)$ and data from the pilot study ( $\mathrm{n}=29$; Serra-Llinares et al. 2018). Both studies were performed in the same fjord in consecutive years and are to a high degree comparable when it comes to methods and study design. However, there are some small differences that must be accounted for when results from both studies are to be combined. First, fish used in the pilot study were caught at sea in mid-June and therefore (1) they were slightly bigger (mean FL $=185 \pm 18 \mathrm{~mm}$ ) than fish in the present study, (2) they could have spent different amounts of time at sea prior to capture, and 
(3) initial mortality immediately after migration to sea, when the fish are the smallest and thus most vulnerable to predation, was not properly captured in the pilot study. Second, fish in the pilot study were not completely lice free prior to tagging: $96 \%$ of the fish were infested with 1 or more lice, with intensities ranging from 2-42 lice fish ${ }^{-1}$. Thus, control fish in the pilot study could arguably be affected to some degree by the lice they carried, possibly obscuring the differences between treatment groups. Last, artificial infestation in the pilot study resulted in more moderate lice loads (estimated relative intensities after artificial infestation between 0.24 and 0.74 lice $\mathrm{g}^{-1}$ fish) compared to the present study, and thus differences in survival between control and infested fish can also be expected to be smaller. Based on all of the above, and to account for potential differences between the 2 studies, Year was added as a covariate in the model, which was finally expressed as:

$h(t)=h_{0}(t) \times \mathrm{e}^{\left(\beta_{1} \text { Group }+\beta_{2} \text { Fish Length }+\beta_{3} \text { Group } \times \text { Fish Length }+\beta_{4} \text { Year }\right)}$

For analysis of return to fresh water, fate/status was set to 1 (returned) for fish that returned to fresh water and were never observed at sea again afterwards, and to 0 (not returned) for fish having their last detection at sea. Fate time $t$ of returned fish was set as the number of days between tagging and fate date. Fate time $t$ for fish that did not return to fresh water was defined by the last observation and specified as right-censored data. Analysis of the Schoefeld residuals showed that the effect of Group (control/ infested) shifted after approximately $60 \mathrm{~d}$, showing a time dependency. We therefore applied a stratified analysis before and after this $60 \mathrm{~d}$ threshold (Period) using the formula:

$h(t)=h_{0}(t) \times \mathrm{e}^{\left(\beta_{1} \text { Group }+\beta_{2} \text { Group } \times \text { Strata }(\text { Period })+\beta_{3} \text { Fish Length }\right)}(3)$

Here, the term $h(t)$ denotes the hazard of returning to fresh water at time $t$.

Differences in distance to fresh water and depth use during the marine migration (i.e. before final return to fresh water) were investigated using mixed models. Daily values (calculated as averages of hourly positions) were used to avoid severe autocorrelation in model residuals. Group (control/infested), fish length (FL in $\mathrm{mm}$ ) and their interaction term were used as covariates in all models, while time of day (day/night) was additionally used for analysis of swimming depths. For this, daytime was defined as the time between sunrise and sunset using data from the Astronomical Applications Department of the US Naval Observatory (www.usno.navy.mil) for the coordinates $58^{\circ} 41^{\prime} \mathrm{N}$, 9 $9^{\circ} 07^{\prime} \mathrm{E}$. Night was defined as the time between sunset and sunrise. Individual daily mean swimming depths were calculated for day and night separately. Fish ID was used as a random effect in all models, as well as a correlation structure (auto-regressive model of order 1) to account for the temporal correlation between consecutive daily data from the same fish.

Distance to fresh water was first modelled using the above described linear mixed model. Exploration of the residuals showed a strong non-linear temporal pattern for infested fish, and consequently week was included as a smoother, which was allowed to differ between experimental groups. The final generalised additive mixed-effect model (GAMM) used was fitted according to the formula (full model):

$$
\begin{aligned}
\text { Dist }_{i j} & =\alpha+\beta_{1} \text { Group }_{i}+\beta_{2} \text { Fish Length }_{i}+\beta_{3} \text { Group }_{i} \\
& \times \text { Fish Length }_{i}+f\left(\text { Week_Group }_{i}\right)+\text { ID }_{i}
\end{aligned}
$$

where Dist $_{i j}$ denotes the mean distance to fresh water for individual $i$ on day $j$, Group G $_{i}$ is the experimental group (control or infested) of individual $i$, Fish Length is FL and $f\left(\right.$ Week_Group $\left._{i}\right)$ is the week-effect smoother for the corresponding experimental group. $I D_{i}$ is the random intercept, which is assumed to be normally distributed with mean 0 and variance $\sigma^{2}$.

For analysis of daily mean swimming depth, the variable was first log-transformed in order to normalize the residuals (prior to log-transformation, $0.2 \mathrm{~m}$ was added to have all observations above 0 ; this was subtracted when back-calculating model coefficients). Daily mean swimming depth showed a nonlinear temporal pattern, and therefore week was included as a smoother, which was allowed to differ between day and night. The final GAMM used was fitted according to the formula (full model):

$$
\begin{aligned}
& \log \left(\text { Depth }_{i j}+0.2\right)=\alpha+\beta_{1} \text { Group }_{i}+\beta_{2} \text { Fish Length }_{i}+\beta_{3} \\
& \text { Time Of Day }_{i j}+\beta_{4} \text { Group }_{i} \times \text { Fish Length }_{i}+\beta_{5} \text { Group }_{i} \\
& \times \text { Time Of Day }_{i j}+f\left(\text { Week_Time Of Day }_{i j}\right)+I_{i}
\end{aligned}
$$

The term Depth $_{i j}$ denotes the mean depth of individual $i$ on day $j$, Group Gr $_{i}$ is the experimental group (control or infested) of individual $i$, Fish Length Lis FL $_{i}$ of individual $i$, Time Of $D a y_{i j}$ denotes the time of the day (day/night) of individual $i$ on day $j$, and $f\left(W e e k_{-}\right.$ Time Of $D a y_{i j}$ ) is the week-effect smoother for the corresponding time of day. $I D_{i}$ is the random intercept, which is assumed to be normally distributed with mean 0 and variance $\sigma^{2}$. 
Each global model (as specified above) was used to generate a model set of all possible sub models, using the function 'dredge' in the R package MuMIn (Bartón 2007). Models were ranked by Akaike's information criterion corrected for small sample size (AICc). The model with the lowest AICc value was considered as 'best fit' and was used to estimate model coefficients. Models with $\triangle \mathrm{AICC}<2$ were considered competing models. Complete model selection tables are presented in the Supplement (Tables S2-S5).

\section{RESULTS}

\subsection{Artificial infestation}

Examination of the laboratory reference groups (Table 1) revealed significant differences in lice loads between control and artificially infested fish. Control fish $(n=14)$ showed a $78 \%$ prevalence (i.e. number of fish carrying 1 or more lice divided by the number of fish examined), indicating either that the fish had time to get infested with lice during the short acclimation period at sea, or that there was a cross-infestation between the 2 tank compartments during the transport by boat to our lab facilities. However, mean intensity (i.e. average number of lice on infested fish) and mean relative intensity (i.e. average number of lice per $g$ of fish weight) remained low in this group $\left(\right.$ mean \pm SD intensity $=1.9 \pm 1.3$ lice fish $^{-1}$; mean relative intensity $=0.05 \pm 0.05$ lice $\mathrm{g}^{-1}$ ). Prevalence in the infested group ( $\mathrm{n}=16$ ) was $100 \%$, with a mean intensity of $65.4 \pm 30.6$ lice fish $^{-1}$ and a mean relative intensity of $2.4 \pm 0.9$ lice $\mathrm{g}^{-1}$.

\subsection{Hydrography}

According to model simulations, surface salinity in Sandnesfjord was lowest in the inner part and increased progressively towards the ocean (Fig. 2). There was a surface layer of brackish water in the inner fjord, with salinities remaining under $15 \mathrm{psu}$ during most of May and June whilst increasing to above 20 psu in July. In the middle fjord, surface salinity remained between 15 and 25 psu during May and June and increased to $30 \mathrm{psu}$ in July. Surface salinity in the outer part of the fjord was between 25 and 30 psu from May to September. Surface temperature was relatively homogeneous throughout the whole length of the fjord and increased progressively from $12^{\circ} \mathrm{C}$ on the release day to a maximum of $19^{\circ} \mathrm{C}$ in late July (Fig. 2).

\subsection{Acoustic tracking and fate assessment}

A total of 143 fish (70 control and 73 infested) provided depth and movement data (2 fish did not provide any data) (Table S1). A substantial proportion of the individuals (approximately $60 \%$ in both groups) moved towards the ocean within the first $2 \mathrm{wk}$ after release and were never observed again in the study area (Fig. 3). We found that 35 fish visited fresh water at least once during the study; of these, 18 individuals (6 control and 12 infested) had the last detection in fresh water and were therefore classified as returns. Twelve of the returns (1 control and 11 infested) returned before 1 August and were therefore classified as early returns. Among early returning fish from the infested group, 6 (of 11) individuals remained in the transition area at least until August 1st, 2 of which were later detected migrating back to the river (the remaining 4 individuals had the last detection as living fish in the transition area); the remaining 5 indi-

Table 1. Size and lice counts from sea trout in the reference groups after artificial infestation. FL: fork length; W: weight; $\mathrm{N}$ lice: number of lice; Rel. int: relative intensity of infestation (number of lice per $\mathrm{g}$ fish weight)

\begin{tabular}{|c|c|c|c|c|}
\hline & FL (mm) & W (g) & $\mathrm{N}$ lice & Rel. int. \\
\hline \multirow[t]{14}{*}{ Control } & 167 & 45 & 1 & 0.02 \\
\hline & 153 & 37 & 0 & 0.00 \\
\hline & 145 & 32 & 1 & 0.03 \\
\hline & 141 & 25 & 5 & 0.20 \\
\hline & 139 & 25 & 1 & 0.04 \\
\hline & 180 & 45 & 1 & 0.02 \\
\hline & 137 & 23 & 1 & 0.04 \\
\hline & 158 & 34 & 0 & 0.00 \\
\hline & 187 & 68 & 1 & 0.01 \\
\hline & 132 & 23 & 0 & 0.00 \\
\hline & 184 & 60 & 2 & 0.03 \\
\hline & 128 & 21 & 2 & 0.10 \\
\hline & 140 & 29 & 4 & 0.14 \\
\hline & 148 & 35 & 2 & 0.06 \\
\hline \multirow[t]{16}{*}{ Infested } & 132 & 22 & 46 & 2.09 \\
\hline & 153 & 31 & 74 & 2.39 \\
\hline & 146 & 28 & 67 & 2.39 \\
\hline & 150 & 29 & 38 & 1.31 \\
\hline & 143 & 27 & 66 & 2.44 \\
\hline & 125 & 23 & 34 & 1.48 \\
\hline & 114 & 14 & 28 & 2.00 \\
\hline & 137 & 24 & 118 & 4.92 \\
\hline & 140 & 25 & 24 & 0.96 \\
\hline & 128 & 18 & 47 & 2.61 \\
\hline & 118 & 15 & 31 & 2.07 \\
\hline & 136 & 25 & 97 & 3.88 \\
\hline & 160 & 41 & 92 & 2.24 \\
\hline & 163 & 37 & 102 & 2.76 \\
\hline & 170 & 46 & 89 & 1.93 \\
\hline & 154 & 35 & 94 & 2.69 \\
\hline
\end{tabular}



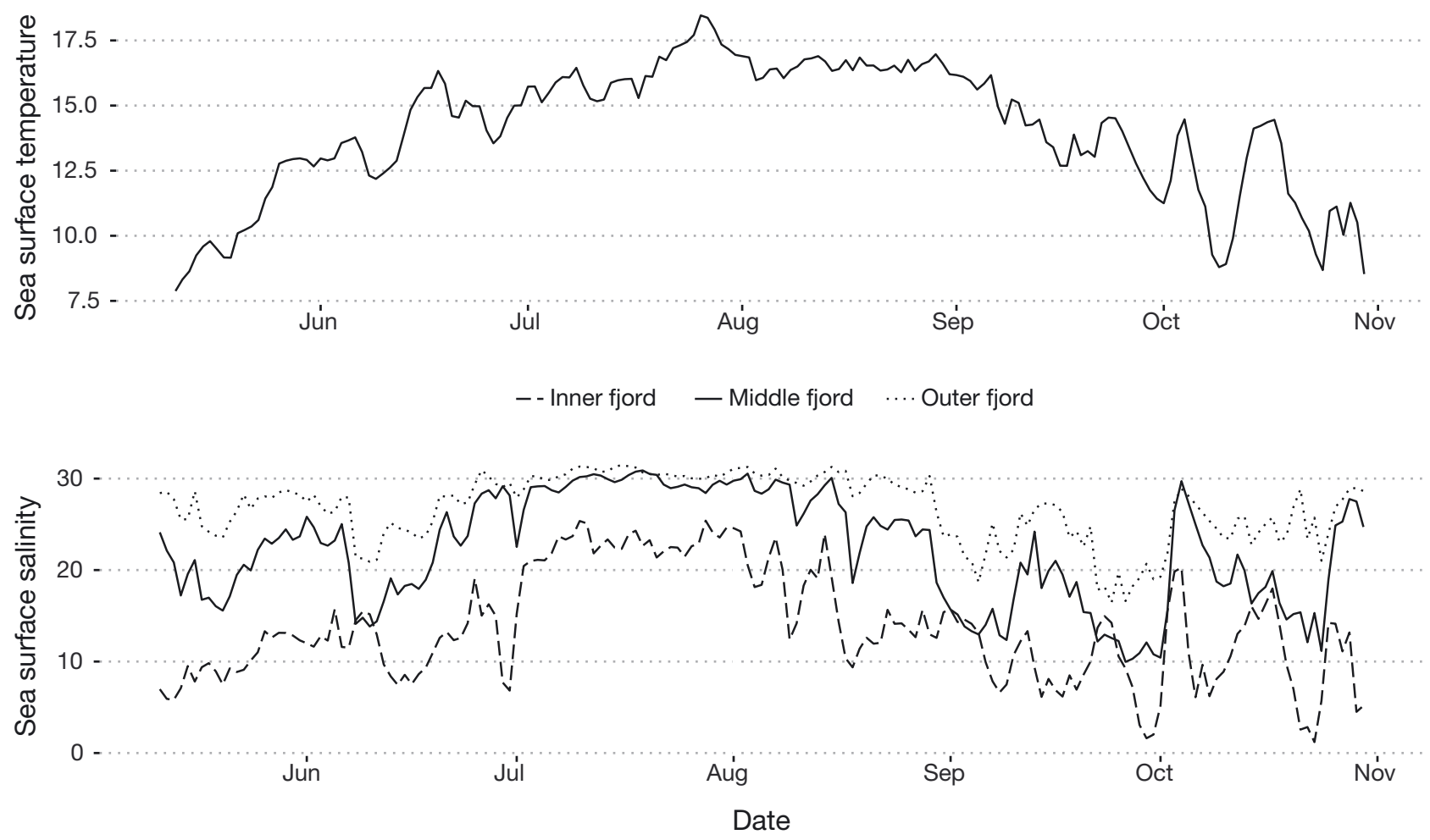

Fig. 2. Modelled sea surface temperatures and salinities in the inner, middle and outer part of Sandnesfjord. Only middle-fjord data are shown for temperature due to little variation along the fjord length

viduals either died (4) or disappeared (1) shortly after premature return to freshwater. A total of 19 individuals, 7 control and 12 infested, were classified as dead. Eleven fish (9 control and 2 infested) were observed alive at sea by 1 October. Nine fish $(6$ infested and 3 control) were detected at the first and closest receiver outside Sandnesfjord, situated approximately $16 \mathrm{~km}$ (sea-way distance) from the innermost part of

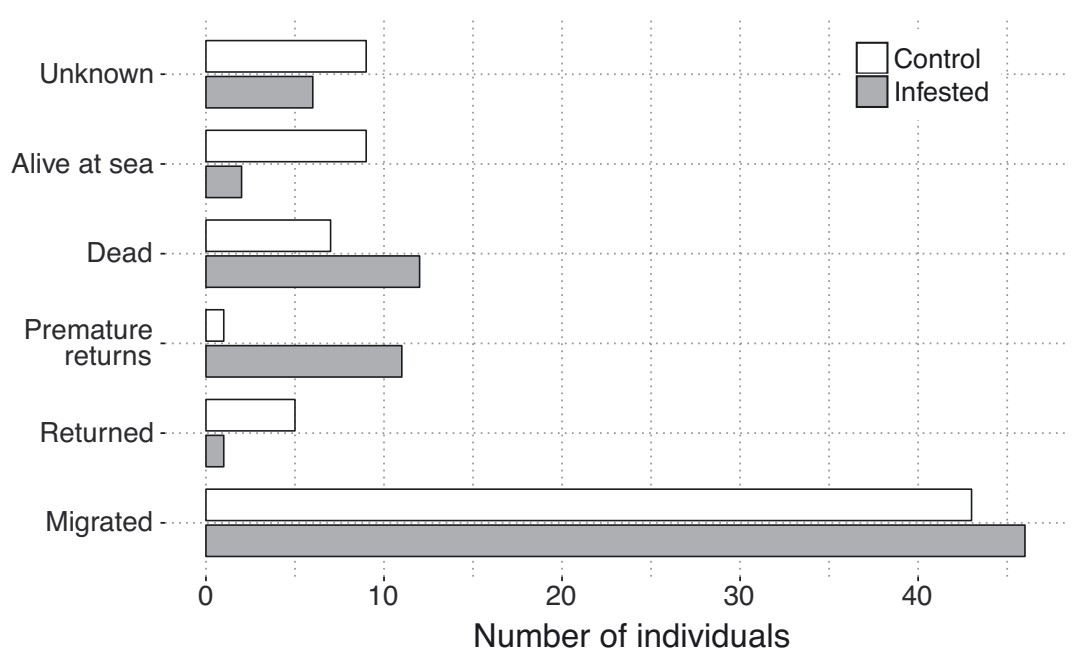

Fig. 3. Summary of fish fates. See Section 2 for further details on fate assessment and Table $\mathrm{S} 1$ in the Supplement for details on individual fates the fjord. Another 6 fish ( 4 infested and 2 control) were further detected at the most distant outer receiver, situated another $9 \mathrm{~km}$ farther south along the coast.

All fish detected in the PIT antenna returning during the first season at sea could also be positioned at the river mouth through detections by the corresponding acoustic receiver. The latest of these detections were used for analysis. None of the fish that disappeared during the study period was later detected in the PIT antenna.

\subsection{Survival}

None of the covariates tested had a statistical effect on the mortality of the fish in 2017 according to the 'best fit' model, which included only the intercept (Table S2a). The top competing model included the variable 'group,' and was practically indistinguishable from the 'best fit' model $(\triangle \mathrm{AICC}=0.22)$. This competing model showed higher, albeit statistically non-significant, mortality for lice-infested fish compared to controls (Coxph, $0.70 \pm 0.51 \mathrm{SE}$; hazard ratio $=2.01,95 \% \mathrm{CI}=0.74-5.46, z=$ 
1.37, $p=0.17$; Figs. 4 \& 5a). Power analysis revealed that, given the structure of the data in this study, a sample size of 362 fish (181 in each group) would be needed to detect an HR between infested and control fish of 2 (as suggested by our results) with an $80 \%$ probability and a confidence of $95 \%$. Furthermore, our actual sample size ( $\sim 70$ fish per group) would only be able to provide statistical significance given an HR between infested and control fish of 2.9 or higher.

Survival analysis on the merged dataset (2016 and 2017 data) revealed a higher mortality risk for lice-infested trout compared to control individuals $(\mathrm{Coxph}, 1.00 \pm 0.49 \mathrm{SE}$; hazard ratio $=2.73,95 \%$

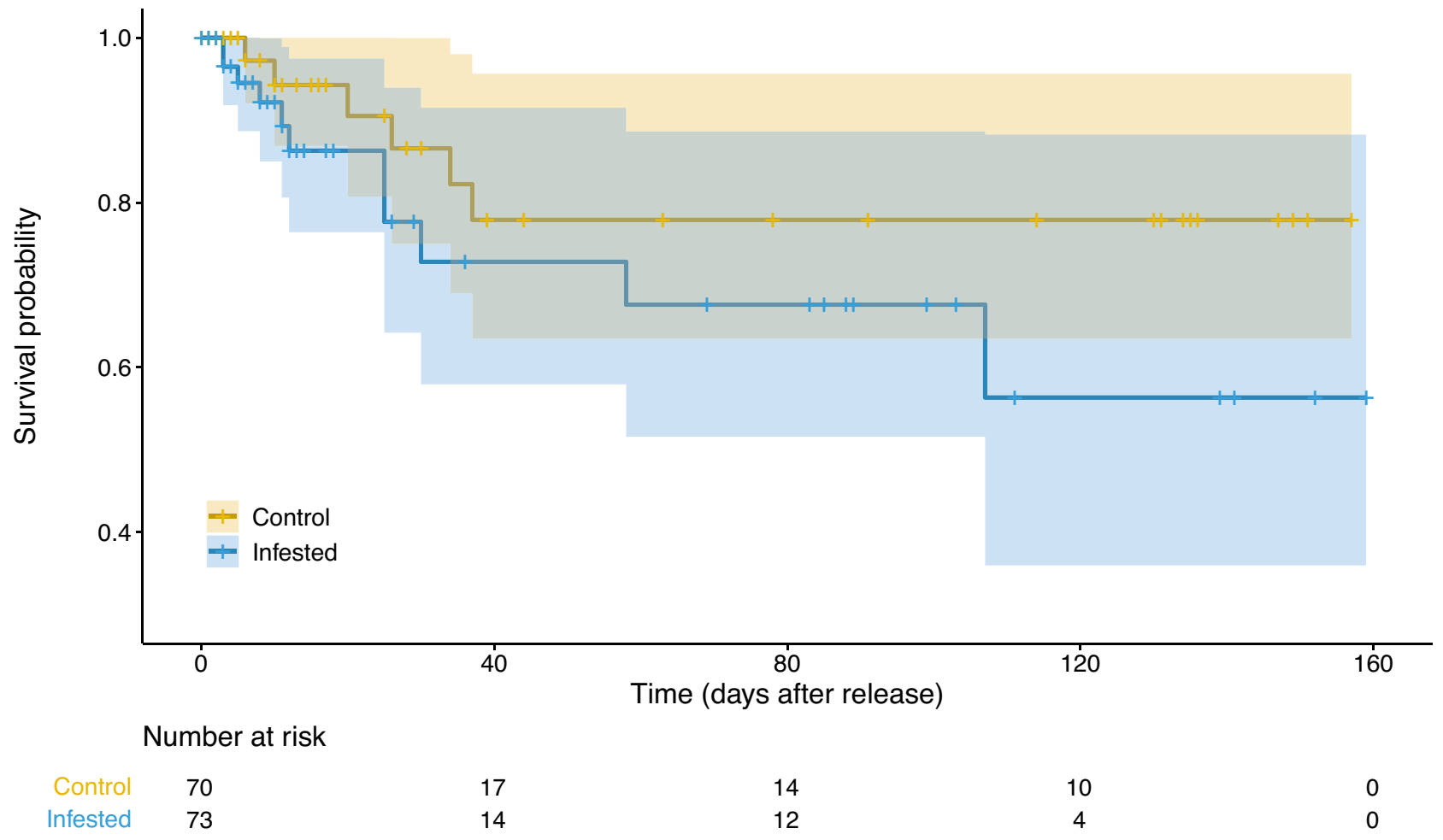

Fig. 4. Survival curves with $95 \%$ confidence bands for control (yellow) and artificially infested (blue) sea trout post-smolts in 2017. Crosses represent censoring points. The table under the graphic shows the number of individuals at risk (not censored) at each time step

Mortality hazard ratio

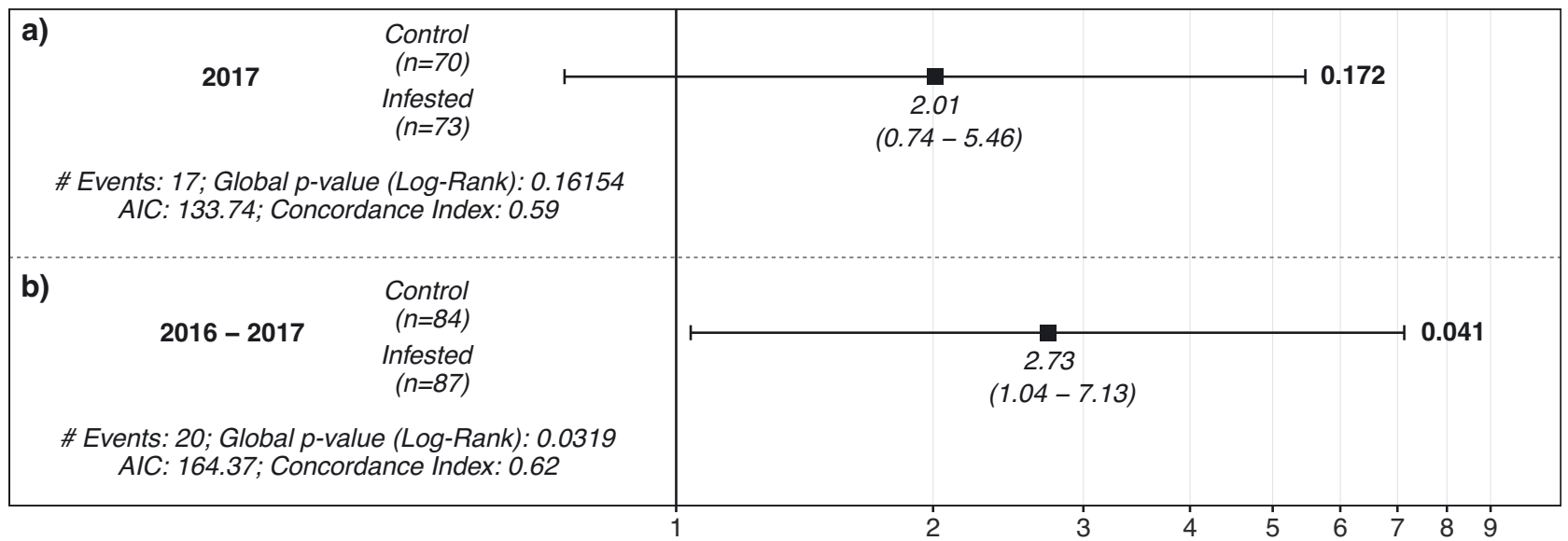

Fig. 5. Mortality hazard ratio between control (reference level) and artificially infested sea trout in (a) the present study (2017 data) and (b) the merged dataset including data from the pilot study. Solid squares and error bars show estimates and $95 \%$ CI, respectively (also noted under the corresponding symbols). Associated p-values are given as annotations on the right side of each graphic. AIC: Akaike's information criterion 
$\mathrm{CI}=1.04-7.13, z=2.04, \mathrm{p}=0.041$; Fig. 5b). Competing models included the effect of year on the mortality hazard ratio between control and infested fish (Table $\mathrm{S} 2 \mathrm{~b}$ ) in the direction of a bigger (although not statistically significant; $p>0.05$ ) difference between groups in 2017. Neither the 'best fit' model nor competing models included fish length as a covariate.

\subsection{Return to fresh water}

Eighteen fish (6 control, 12 infested) returned to fresh water. The timing of the returns was significantly earlier for infested (18 $\pm 26 \mathrm{~d}$ after release) than for control fish $(100 \pm 49$ days; $t$-test, $\mathrm{p}=0.003)$, with 12 individuals ( 1 control and 11 infested) returning before 1 August. The 'best fit' model included both fish length and the interaction group:strata (period) (Table S3), both having a significant effect on the probability of return. During the first $60 \mathrm{~d}$ of the migration (period 1), infested fish had a higher probability of returning to fresh water compared to control fish of the same size (Coxph, $2.43 \pm 1.05 \mathrm{SE}$; hazard ratio $=11.33,95 \% \mathrm{CI}=1.45-88.4, \mathrm{z}=2.32, \mathrm{p}=$ 0.021; Figs. 6 \& 7). After $60 \mathrm{~d}$ (period 2), the return probability for infested fish decreased until becom- ing lower, although not statistically significant, than that of their control counterparts (Coxph, $-1.16 \pm$ $1.12 \mathrm{SE}_{\text {; }}$ hazard ratio $=0.31,95 \% \mathrm{CI}=0.03-2.84, z=$ 1.03, p = 0.30; Figs. $6 \&$ 7). In general (both periods), bigger fish had a higher probability of returning to fresh water $\left(\mathrm{Coxph}, 0.03 \pm 0.02 \mathrm{SE}_{\text {; }}\right.$ hazard ratio $=$ $1.04,95 \% \mathrm{CI}=1.01-1.07, z=2.31, \mathrm{p}=0.021$ ).

\subsection{Distance to fresh water}

Lice-infested trout remained closer to the estuary compared to control fish while at sea (i.e. before they eventually terminated their sea migration and moved back to fresh water or into the transition area) (Table 2). This difference was especially noticeable after the first $3 \mathrm{wk}$ post release and remained a consistent pattern for the rest of the study period (Fig. 8). There was a significant interaction between group and fish length, with fish length having a small positive effect for control fish and a stronger and negative effect for infested fish. The average distance to fresh water for a control fish of average size $(\mathrm{FL}=180 \mathrm{~mm})$ was approximately $6 \mathrm{~km}$, with smaller fish staying slightly closer (approximately $80 \mathrm{~m}$ for each $1 \mathrm{~cm}$ increase in body length). For an infested fish of the

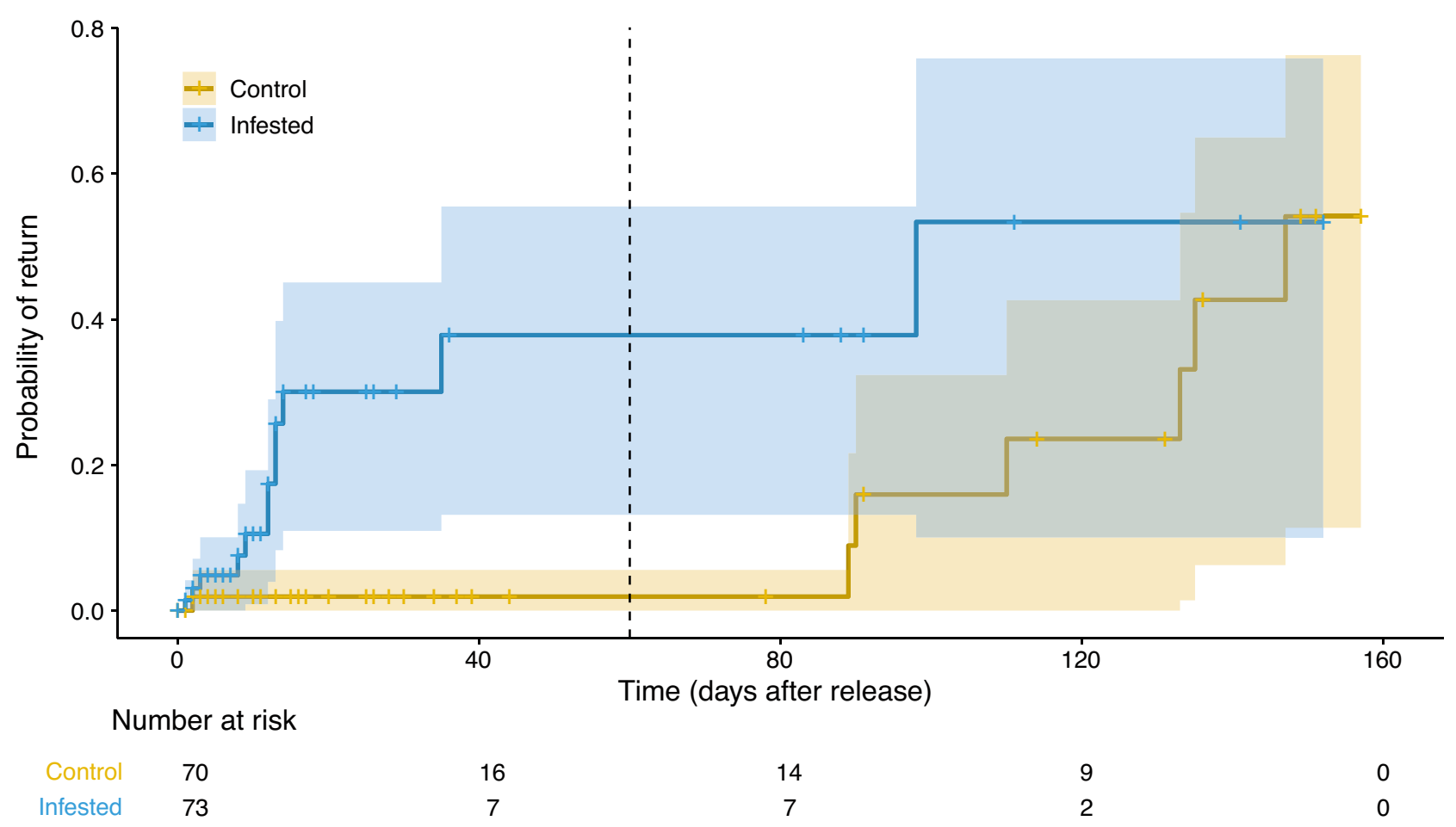

Fig. 6. Probability of return to fresh water with $95 \%$ confidence bands for control (yellow) and artificially infested (blue) sea trout post-smolts. Crosses represent censoring points. Dotted line indicates Day 60 post release, separating period 1 from period 2 in the stratified analysis. The table under the graphic shows the number of individuals at risk (not censored) at each time step 
Return hazard ratio

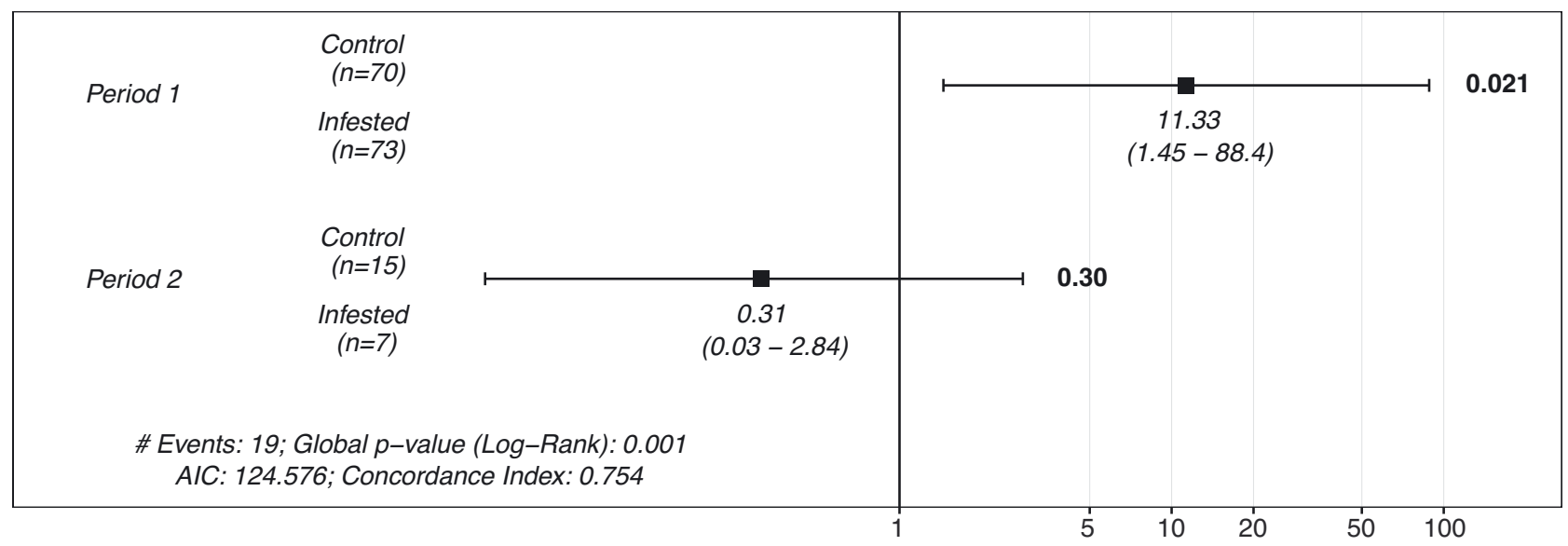

Fig. 7. Hazard ratio for freshwater return between control (reference level) and artificially infested sea trout before (period 1) and after (period 2) $60 \mathrm{~d}$ post release. Solid squares and error bars show estimates and $95 \% \mathrm{CI}$, respectively (also noted under the corresponding symbols). Associated p-values are given as annotations on the right side of each graphic. AIC: Akaike's information criterion

same size, the corresponding distance was estimated at approximately $2.5 \mathrm{~km}$, with larger fish remaining closer than smaller fish (approximately $565 \mathrm{~m}$ closer for each $1 \mathrm{~cm}$ increase in body length). The model explained $46 \%$ of the variance. All candidate models evaluated are shown in Table S4.

\subsection{Depth use}

Trout resided close to the surface during the whole marine migration, with more than $98 \%$ of all detections recorded at depths shallower than $3 \mathrm{~m}$. Only 8 fish $(6 \%)$ were detected performing 1 or more dives $>15 \mathrm{~m}$ during the whole study. Mean swimming depth during the whole marine migration was $0.78 \mathrm{~m}$ (range of means for individuals: $0.04-2.54 \mathrm{~m}$ ), with individuals staying shallower at

Table 2. Results from generalised additive mixed-effects models (GAMMs) for distance to fresh water and swimming depth, modelled as a function of fish length (fork length in mm), group (control/infested) and time of day (day/night; included only in the analysis of swimming depth). ${ }^{*}$ Significant values $(\mathrm{p}<0.05)$

\begin{tabular}{|lrrrl|}
\hline & Estimate & $\mathrm{SE}$ & $t$ & $\mathrm{p}(>|t|)$ \\
\hline Distance to fresh water & & & & \\
(Intercept) & 4781.07 & 2414.21 & 1.980 & $0.048^{*}$ \\
Fish length & 8.08 & 13.46 & 0.600 & 0.548 \\
Group (infested) & 7481.47 & 3306.21 & 2.263 & $0.024^{*}$ \\
Fish length: Group (infested) & -56.51 & 18.30 & -3.088 & $0.002^{*}$ \\
Log (Swimming depth + 0.2) & & & & \\
(Intercept) & -0.746 & 0.331 & -2.256 & $0.024^{*}$ \\
Fish length & 0.005 & 0.002 & 3.010 & $0.003^{*}$ \\
Group (infested) & -0.134 & 0.052 & -2.576 & $0.011^{*}$ \\
Time of day (night) & -0.656 & 0.011 & -59.809 & $0.000^{*}$ \\
Group (infested): Time of day (night) & 0.122 & 0.019 & 6.510 & $0.000^{*}$ \\
\hline
\end{tabular}

\section{DISCUSSION}

In this study, we documented parasite-induced mortality and significant behavioural changes in trout post-smolts as a consequence of a heavy lice infestation. The lice levels artificially imposed on experimental fish in our study were estimated at 65 lice fish $^{-1}$ on average, or a relative intensity of 2.4 lice $\mathrm{g}^{-1}$. This is well above the expected mortalityinducing threshold for trout, estimated at 0.3 lice $^{-1}$ (see Taranger et al. 2015), and individuals carrying such high lice loads represent only a small fraction (between 4 and $5 \%$ ) of all trout sampled in the Norwegian Salmon Lice Surveillance Program (R. Nilsen pers. obs.). However, in some areas with intensive fish farming, the percentage of fish carrying 


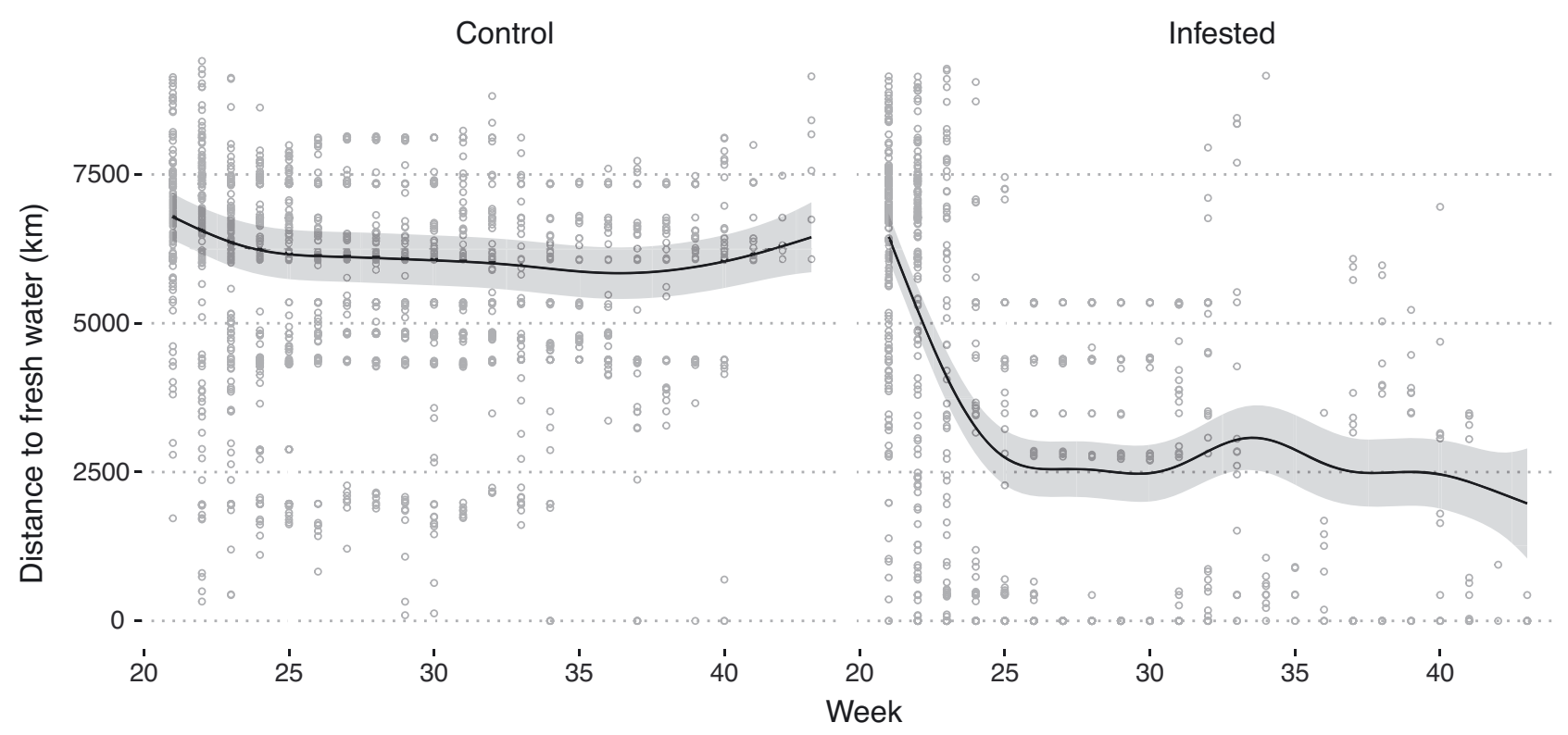

Fig. 8. Observed (points) and predicted (lines and shaded areas, representing estimates with 95\% CI) distance to fresh water for individual fish by experimental group (control or infested). Predictions are made for a fish of average size (180 mm fork length)

$>65$ lice (or relative intensities $>2$ lice $\mathrm{g}^{-1}$ ) has occasionally been registered to be as high as $70 \%$ of all fish sampled (R. Nilsen pers. obs.). Thus, lice loads such as that in this study may be extreme and represent perhaps only a 'worst-case' situation, but they are not implausible under the current scenario in Norway.

\subsection{Role of lice in post-smolt mortality}

Dead and moribund trout observed in estuaries have been linked to lice infestations (Tully et al. 1993a,b, Birkeland 1996), but proof of a causal relationship remains elusive (Thorstad et al. 2015). Direct observation of mortality in free-ranging fish at sea is

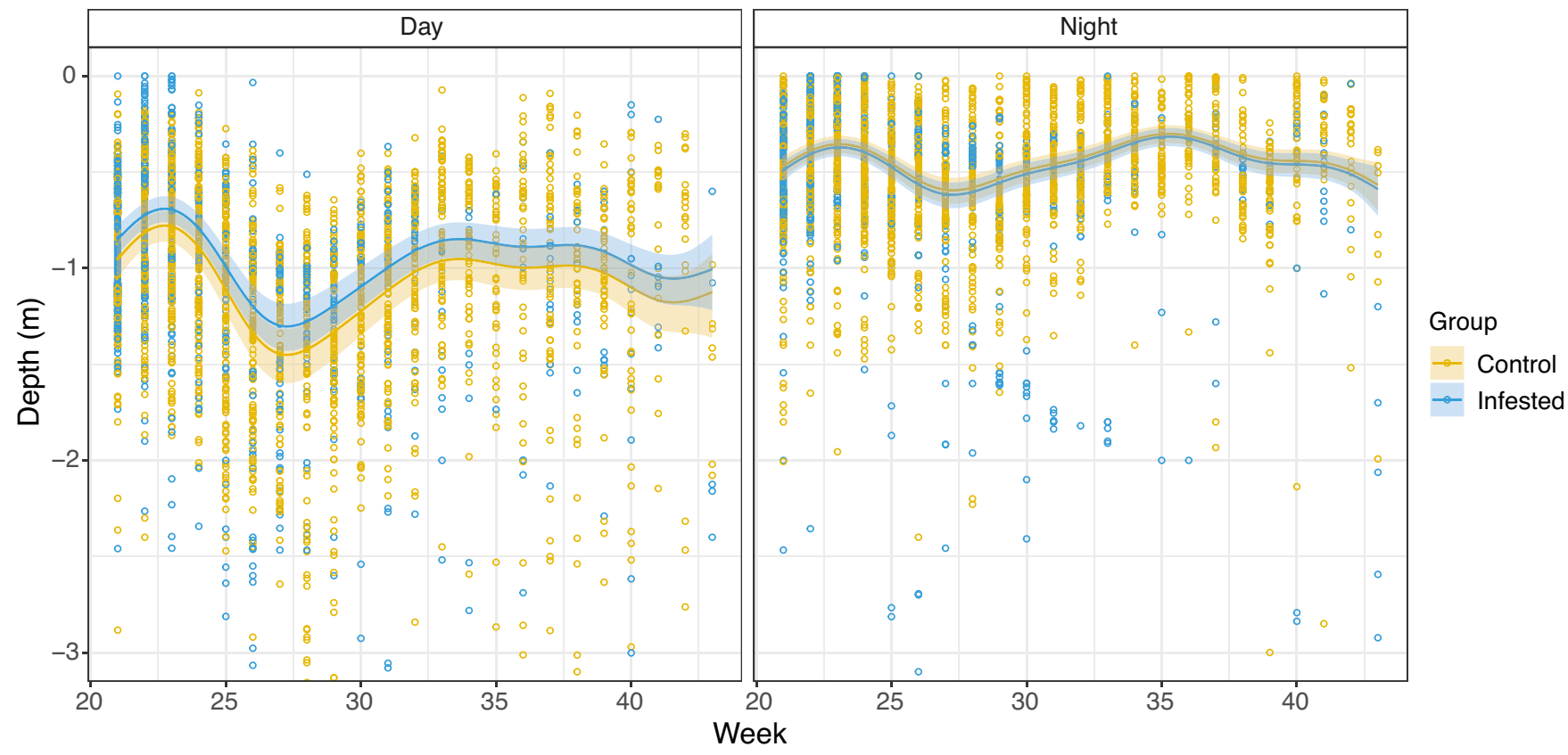

Fig. 9. Observed swimming depths for control (yellow dots) and infested (blue dots) sea trout post-smolts during day and night. Lines and shaded areas represent predicted swimming depths and $95 \% \mathrm{CI}$, respectively, for a fish of average size $(180 \mathrm{~mm}$ fork length) 
difficult, and studies are often limited by low numbers of returning individuals and large natural variation in mortality. In this study, we document a higher mortality of lice-infested trout post-smolts compared to non-infested control individuals, with an estimated HR of 2.7 (95\% CI $=1.04-7.13)$. In other words, the probability of a trout post-smolt to survive the first summer at sea was reduced by almost two-thirds when infested with a heavy lice load. These results are in agreement with Skaala et al. (2014), who showed that the survival of sea trout protected against lice was nearly doubled compared to non-treated fish, in a large-scale field experiment involving PIT-tagging of 2000 fish over $2 \mathrm{yr}$ in a fjord with intensive salmon farming in Norway. To our knowledge, this is the only other study showing the impact of lice on the survival of wild sea trout in their natural environment. Other studies have not found a correlation between prophylactic treatment and marine survival of trout post-smolts, but these are (as stated by the authors of those studies) likely constrained by methodological caveats and low statistical power (Gjelland et al. 2014, Halttunen et al. 2018).

\subsection{Salmon lice as a causal agent for premature return}

In addition to an increase in mortality for liceinfested individuals, lice infestation triggered the almost immediate return of the fish to fresh water in our study. Most of the infested fish that did not rapidly disperse from the study area actively sought fresh or brackish waters within the first few days post release. Of these, almost half were never detected again at sea, having spent on average only $18 \mathrm{~d}$ feeding in the marine environment. Given a water temperature of around $12-13^{\circ} \mathrm{C}$ during that period, the attached copepodites had presumably reached the preadult stage around that time (Stien et al. 2005). Premature return to fresh water of lice-infested trout has been previously documented in Ireland, Scotland and Norway (Tully et al. 1993a, Birkeland \& Jakobsen 1997, Pert et al. 2009). This return to fresh water is suggested to allow the fish to delouse and regain osmotic balance in order to survive the infestation (Birkeland \& Jakobsen 1997, Bjørn et al. 2001). Even though preadult and adult lice are the most detrimental stages for the host fish (Bjørn \& Finstad 1998), heavy infestations with copepodites and chalimus stages can also cause skin damage and hydromineral imbalance and can trigger a stress response in trout (Bjørn \& Finstad 1997, Poole et al. 2000, Bjørn et al.
2001). Thus, heavily infested individuals may return to fresh water even before the offset of severe liceinduced physiological effects. Additionally, larger fish had a higher probability than smaller fish of returning to fresh water in both groups throughout our study. Higher return rates for larger trout postsmolts can be expected due to size-dependent mortality (Thorstad et al. 2015, 2016, Flaten et al. 2016). According to results from our survival analysis, the effect of fish size on the probability of return to fresh water cannot be attributed to size-dependent mortality, since no effect of fish size was detected on the probability of surviving the sea journey. However, this could be an artifact of low statistical power combined with large inter-individual variability.

\subsection{Other behavioural adaptations to lice infestation}

Of the 11 lice-infested fish that returned prematurely to fresh water in our study, 7 remained in the transition area for the rest of the migration. This is likely because the costs of ionic regulation are lower in brackish water than in both fresh and sea water (Rao 1968, Otto 1971, Brett \& Groves 1979). Liceinfested individuals that did not prematurely return to fresh water spent most of the feeding migration in the innermost part of the fjord, characterized by lower surface salinities and shorter distance to the native river. Unlike lice-infested individuals, most control fish exploited the feeding grounds in the outer fjord and spent on average $100 \mathrm{~d}$ feeding at sea before returning to fresh water.

The vertical profiles of the trout movements showed a strong preference for the upper $3 \mathrm{~m}$ of the water column. Average swimming depths were slightly shallower at night than in the daytime, indicating smallscale diel vertical movements. These results agree with other studies investigating the behaviour of wild trout in the marine environment (Lyse et al. 1998, Eldøy et al. 2017, Kristensen et al. 2018). However, most of these studies have focused on veteran migrants, mainly due to technological constraints such as tag size for telemetry studies. Thus, our findings provide a new insight into the behaviour and habitat use of trout post-smolts during their sea journey. Liceinfested fish resided slightly closer to the surface compared to control fish during daytime in our study. Lice-infested trout have been previously reported to swim closer to the surface (Gjelland et al. 2014, A. Mohn unpublished data). Because the upper water layers are typically more influenced by rivers and 
other freshwater sources, this can be seen as a behavioural adaptation to counteract the osmoregulatory problems derived from the parasitic infestation. All in all, it seems likely that lice-infested individuals in our study were seeking fresh and brackish water by adjusting both their horizontal and vertical use of the fjord.

\subsection{Indirect and delayed impacts}

Growth in the sea is generally better than in fresh water (L'Abee-Lund et al. 1989, Jonsson \& L'Abée Lund 1993, Frier 1994), and growth is positively correlated with the duration of the sea sojourn (Berg \& Jonsson 1990). Thus, an abrupt interruption of the feeding migration after just a few weeks at sea, as reported in this study, may result in a significant loss of feeding and growth opportunities. Birkeland (1996) observed prematurely returned, lice-infested trout re-entering the sea after a median stay of $38 \mathrm{~d}$ in fresh water. By that time, they had lost $23.5 \%$ of their body mass. Similarly, Fjørtoft et al. (2014) calculated a $20-40 \%$ reduction in summer growth in the Etne River, western Norway, during a period of intensive farming, and suggested lice as a possible cause. In Ireland, proximity to salmon aquaculture and associated louse infestation pressure have been demonstrated to reduce weight in wild trout post-smolts by up to $9 \mathrm{~g}$ (at an average length of $18 \mathrm{~cm}$ ), thus reducing Fulton's condition factor by ca. 0.15 (Shephard et al. 2016). Reduced summer growth may additionally reduce the probability of surviving through the following winter, since individuals that have not attained a critical size or sufficient energy stores may be unable to meet minimum metabolic requirements during winter and die (Jensen et al. 2018). Also, as fecundity increases with body size (Jonsson 1985, L'Abée Lund \& Hindar 1990) and age at first maturity is influenced by growth rate at sea (L'Abée-Lund 1994, Vollset et al. 2014), reduced growth and energy reserves as a result of louse infestation may reduce fecundity and reproductive success.

\subsection{Consequences for populations}

It has been suggested that an increase in marine mortality and a reduction in sea growth due to lice or other factors affecting trout in the marine environment can result in a population shift in lifehistory strategy (Thorstad et al. 2015). Gargan et al. (2016) showed significant changes in quantitative life-history traits in the trout population in the Erriff River, western Ireland, after the establishment of salmon farming in the local estuary. These changes included a reduction in the number and size of trout kelts, the estimated number of eggs deposited, the sea trout rod catch, the proportion of older $(1+$ and $2+$ sea age) fish and the frequency of repeat spawners. Similarly, Butler \& Walker (2006) recorded a collapse in sea trout rod catch in the River Ewe/Loch Maree system, Scotland, in 1988. This collapse was related to an apparently unprecedented reduction in marine growth and survival, changes that were at least partly attributable to lice epizootics from nearby salmon farms. Reduced marine survival and growth as a result of lice epizootics may also shift the balance between costs and profits of the marine migration and ultimately lead to a decrease in the frequency of sea-run brown trout (Gargan et al. 2006).

\subsection{Concluding remarks}

In summary, our study reports a reduced survival of trout post-smolts as a direct consequence of a heavy lice infestation, suggesting that in areas with high lice infestation pressure, the number of trout postsmolts surviving the first season at sea may be significantly reduced. Furthermore, we document an altered migration behaviour of lice-infested individuals, including the abrupt interruption of the feeding migration after just a few weeks at sea. This interruption could result in a significant loss of feeding and growth opportunities for migrating fish, further affecting later survival and fecundity and ultimately having a potential impact at the population level. Despite trout being a culturally, socially and economically important species in Norway and elsewhere, there are still important knowledge gaps on its population biology and potential responses to parasites. This is partly explained by a complex and flexible life history with a wide range of strategies within and between populations. Notwithstanding the challenges, this information is urgently needed. Salmon lice epizootics are currently regarded as a major threat for wild salmonids in Norway (Costello 2009, Taranger et al. 2015, Forseth et al. 2017) and other salmon-producing countries, and robust scientific knowledge on the impact of lice on individuals and populations is key to the implementation of sound conservation strategies.

Acknowledgements. Funding was provided by the Institute of Marine Research, Norway, project no. 14650. We thank Bjørnar Skold, Institute of Marine Research (Bergen), for 
providing salmon lice copepodites. We also thank Rolf Leo Waage Nilsen for reporting the recapture of one of our tagged individuals. Finally, we thank Diego Pavón Jordán, Norwegian Institute for Nature Research, and Agnes Mohn, Institute of Marine Research (Tromsø), for statistical and technical support.

\section{LITERATURE CITED}

Albretsen JE, Sperrevik AK, Staalstrøm A, Sandvik AD and others (2011) NorKyst-800 report no. 1: User manual and technical descriptions. Fisken og havet, report from the Institute of Marine Research 2/2011. www.hi.no/ resources/publikasjoner/fisken-og-havet/2011/fh_2-2011 _til_web.pdf

Bartón K (2007) MuMIn: multi-model inference. R package version 1.5.2. http://CRAN.R-project.org/package=MuMIn

Berg OK, Jonsson B (1990) Growth and survival rates of the anadromous trout, Salmo trutta, from the Vardnes River, northern Norway. Environ Biol Fishes 29:145-154

* Birkeland K (1996) Consequences of premature return by sea trout (Salmo trutta) infested with the salmon louse (Lepeophtheirus salmonis Krøyer): migration, growth, and mortality. Can J Fish Aquat Sci 53:2808-2813

Birkeland K, Jakobsen PJ (1997) Salmon lice, Lepeophtheirus salmonis, infestation as a causal agent of premature return to rivers and estuaries by sea trout, Salmo trutta, juveniles. Environ Biol Fishes 49:129-137

Bjørn P, Finstad B (1997) The physiological effects of salmon lice infection on sea trout post smolts. Nord J Freshw Res 73:60-72

Bjørn PA, Finstad B (1998) The development of salmon lice (Lepeophtheirus salmonis) on artificially infected post smolts of sea trout (Salmo trutta). Can J Zool 76:970-977

Bjørn P, Finstad B, Kristoffersen R (2001) Salmon lice infection of wild sea trout and Arctic char in marine and freshwaters: the effects of salmon farms. Aquacult Res 32:947-962

Brett JR, Groves TDD (1979) Physiological energetics. Fish Physiol 8:279-352

Butler J, Walker A (2006) Characteristics of the sea trout Salmo trutta L. stock collapse in the River Ewe (Wester Ross, Scotland) in 1988-2001. In: Harris G, Milner N (eds) Sea trout: biology, conservation and management. Blackwell Publishing, Oxford, p 45-59

* Chapman BB, Hulthén K, Brodersen J, Nilsson PA, Skov C, Hansson LA, Brönmark C (2012) Partial migration in fishes: causes and consequences. J Fish Biol 81:456-478

Chaput GJ, Jones R (2004) Catches of downstream migrating fish in fast-flowing rivers using rotary screw traps. Can Manuscr Rep Fish Aquat Sci 2688:1-14

* Costello MJ (2009) How sea lice from salmon farms may cause wild salmonid declines in Europe and North America and be a threat to fishes elsewhere. Proc R Soc B 276: 3385-3394

Dawson L (1998) The physiological effects of salmon lice (Lepeophtheirus salmonis) infections on returning postsmolt sea trout (Salmo trutta L.) in western Ireland, 1996. ICES J Mar Sci 55:193-200

* Dingle H, Drake VA (2007) What is migration? Bioscience 57:113-121

Egbert GD, Erofeeva SY (2002) Efficient inverse modeling of barotropic ocean tides. J Atmos Ocean Technol 19:183-204

Eldøy SH, Davidsen JG, Thorstad EB, Whoriskey FG and others (2017) Marine depth use of sea trout Salmo trutta in fjord areas of central Norway. J Fish Biol 91:1268-1283

Espeland SH, Albretsen J, Olsen EM, Bodvin T (2015) Modelling drift of pelagic offspring: the importance of egg surveys in providing a realistic model initialization. ICES J Mar Sci 72:2578-2589

Euzenat G, Fournel F, Richard A (1999) Sea trout (Salmo trutta L.) in Normandy and Picardy. In: Baglinière JL, Maisse G (eds) Biology and ecology of the brown and sea trout. Springer, London, p 175-203

Ferguson A (2006) Genetics of sea trout, with particular reference to Britain and Ireland. In: Harris G, Milner N (eds) Sea trout: biology, conservation and management. Blackwell Publishing, Oxford, p 157-182

Fjørtoft HB, Borgstrøm R, Skaala Ø (2014) Differential changes in growth patterns of anadromous brown trout and Atlantic salmon from the River Etneelva over a 25year period. Mar Biol Res 10:301-307

Flaten AC, Davidsen JG, Thorstad EB, Whoriskey F and others (2016) The first months at sea: marine migration and habitat use of sea trout Salmo trutta post smolts. J Fish Biol 89:1624-1640

* Forseth T, Barlaup BT, Finstad B, Fiske P and others (2017) The major threats to Atlantic salmon in Norway. ICES J Mar Sci 74:1496-1513

Frier J (1994) Growth of anadromous and resident brown trout with different life histories in a Danish lowland stream. Nord J Freshw Res 64:58-70

Gargan P, Roche W, Forde G, Ferguson A (2006) Characteristics of the sea trout (Salmo trutta L.) stocks from the Owengowla and Invermore fisheries, Connemara, Western Ireland, and recent trends in marine survival. In: Harris G, Milner N (eds) Sea trout: biology, conservation and management. Blackwell Publishing, Oxford, p 60-75

Gargan P, Forde G, Hazon N, Russell D, Todd C (2012) Evidence for sea lice-induced marine mortality of Atlantic salmon (Salmo salar) in western Ireland from experimental releases of ranched smolts treated with emamectin benzoate. Can J Fish Aquat Sci 69:343-353

Gargan PG, Kelly FL, Shephard S, Whelan KF (2016) Temporal variation in sea trout Salmo trutta life history traits in the Erriff River, western Ireland. Aquacult Environ Interact 8:675-689

*Gjelland KØ, Serra-Llinares RM, Hedger RD, ArechavalaLopez P and others (2014) Effects of salmon lice infection on the behaviour of sea trout in the marine phase. Aquacult Environ Interact 5:221-233

Gross MR, Coleman RM, McDowall RM (1988) Aquatic productivity and the evolution of diadromous fish migration. Science 239:1291-1293

* Haidvogel DB, Arango H, Budgell WP, Cornuelle BD and others (2008) Ocean forecasting in terrain-following coordinates: formulation and skill assessment of the Regional Ocean Modeling System. J Comput Phys 227:3595-3624

* Halttunen E, Gjelland KØ, Hamel S, Serra-Llinares RM and others (2018) Sea trout adapt their migratory behaviour in response to high salmon lice concentrations. J Fish Dis 41:953-967

* Hamre LA, Glover KA, Nilsen F (2009) Establishment and characterisation of salmon louse (Lepeophtheirus salmonis (Krøyer 1837)) laboratory strains. Parasitol Int 58:451-460

Haraldstad T, Güttrup J (2015) Sjøoverlevelse til sjøauren i Storelva. En oppsummering av resultater fra Pit-merkeforsøk 2010-2014. Rapport 6840-2015. NIVA, Grimstad

Haraldstad T, Güttrup J, Höglund E (2016) Slep av laksesmolt fra Storelva som avbøtende tiltak mot estuarine 
blandsoner-Smoltårgang. Rapport 7079-2016. NIVA, Grimstad (in Norwegian with English summary)

H Haraldstad T, Kroglund F, Kristensen T, Jonsson B, Haugen TO (2017) Diel migration pattern of Atlantic salmon (Salmo salar) and sea trout (Salmo trutta) smolts: an assessment of environmental cues. Ecol Freshw Fish 26: 541-551

Haraldstad T, Höglund E, Kroglund F, Lamberg A, Olsen EM, Haugen TO (2018) Condition-dependent skipped spawning in anadromous brown trout (Salmo trutta). Can J Fish Aquat Sci 75:2313-2319

*Helland IP, Uglem I, Jansen PA, Diserud OH, Bjørn PA, Finstad B (2015) Statistical and ecological challenges of monitoring parasitic salmon lice infestations in wild salmonid fish stocks. Aquacult Environ Interact 7:267-280

Heuch PA, Mo TA (2001) A model of salmon louse production in Norway: effects of increasing salmon production and public management measures. Dis Aquat Org 45:145-152

Huserbråten MBO, Moland E, Albretsen J (2018) Cod at drift in the North Sea. Prog Oceanogr 167:116-124

Jansen PA, Kristoffersen AB, Viljugrein H, Jimenez D, Aldrin M, Stien A (2012) Sea lice as a density-dependent constraint to salmonid farming. Proc R Soc B 279:2330-2338

* Jensen AJ, Finstad B, Fiske P, Forseth T and others (2018) Relationship between marine growth and sea survival of two anadromous salmonid fish species. Can J Fish Aquat Sci 75:621-628

Jensen KW (1968) Sea trout (Salmo trutta L.) of the River Istra, Western Norway. In: Harris G, Milner N (eds) Sea trout: biology, conservation and management. Blackwell Publishing, Oxford, p 187-213

Jonsson B (1985) Life history patterns of freshwater resident and sea run migrant brown trout in Norway. Trans Am Fish Soc 114:182-194

Jonsson B, Jonsson N (1993) Partial migration: niche shift versus sexual maturation in fishes. Rev Fish Biol Fish 3: 348-365

Jonsson B, Jonsson N (2006) Life history of the anadromous trout Salmo trutta. In: Harris G, Milner N (eds) Sea trout: biology, conservation and management. Blackwell Publishing, Oxford, p 196-223

Jonsson B, L'Abée Lund J (1993) Latitudinal clines in life history variables of anadromous brown trout in Europe. J Fish Biol 43:1-16

Karlsen Ø, Asplin L, Finstad B, Sandvik AD and others (2018) Effekten av nasjonale laksefjorder på risikoen for lakselusinfestasjon hos vill laksefisk langs norskekystenSluttrapportering av ordningen med nasjonale laksefjorder. Rapport fra Havforskningen nr 2-2018. Fisken og Havet, Bergen

*Klemetsen A, Amundsen PA, Dempson J, Jonsson B, Jonsson N, O'Connell M, Mortensen E (2003) Atlantic salmon Salmo salar L., brown trout Salmo trutta L. and Arctic charr Salvelinus alpinus (L.): a review of aspects of their life histories. Ecol Freshw Fish 12:1-59

Knutsen J, Knutsen H, Olsen E, Jonsson B (2004) Marine feeding of anadromous Salmo trutta during winter. J Fish Biol 64:89-99

Kristensen ML, Righton D, del Villar-Guerra D, Baktoft $H$, Aarestrup K (2018) Temperature and depth preferences of adult sea trout Salmo trutta during the marine migration phase. Mar Ecol Prog Ser 599:209-224

Krkošek M, Lewis MA, Volpe JP (2005) Transmission dynamics of parasitic sea lice from farm to wild salmon. Proc R Soc B 272:689-696
L'Abée-Lund JH (1994) Effect of smolt age, sex and environmental conditions on sea age at first maturity of anadromous brown trout, Salmo trutta, in Norway. Aquaculture 121:65-71

* L'Abée Lund J, Hindar K (1990) Interpopulation variation in reproductive traits of anadromous female brown trout, Salmo trutta L. J Fish Biol 37:755-763

${ }^{*} L$ 'Abee-Lund JH, Jonsson B, Jensen AJ, Saettem LM, Heggberget TG, Johnsen BO, Naesje TF (1989) Latitudinal variation in life-history characteristics of sea-run migrant brown trout Salmo trutta. J Anim Ecol 58:525-542

Kucas M, Baras E (2001) Migration of freshwater fishes. Blackwell Science, Oxford

Kyse A, Stefansson S, Fernö A (1998) Behaviour and diet of sea trout post smolts in a Norwegian fjord system. J Fish Biol 52:923-936

* Müller M, Homleid M, Ivarsson KI, Køltzow MA and others (2017) AROME-MetCoOp: a Nordic convective-scale operational weather prediction model. Weather Forecast 32:609-627

Olsen E, Knutsen H, Simonsen J, Jonsson B, Knutsen J (2006) Seasonal variation in marine growth of sea trout, Salmo trutta, in coastal Skagerrak. Ecol Freshw Fish 15:446-452

Otto RG (1971) Effects of salinity on the survival and growth of pre-smolt coho salmon (Oncorhynchus kisutch). J Fish Res Board Can 28:343-349

Pert CC, Raffell J, Urquhart K, Weir SJ, Kantola KMH, Bricknell IR (2009) The pathogen burden of early returning sea trout (Salmo trutta L.) infected with Lepeophtheirus salmonis (Kroyer, 1837), in the River Shieldaig, Scotland. Bull Eur Assoc Fish Pathol 29:210-216

* Poole W, Nolan D, Tully O (2000) Modelling the effects of capture and sea lice [Lepeophtheirus salmonis (Krøyer)] infestation on the cortisol stress response in trout. Aquacult Res 31:835-841

Pratten D, Shearer W (1983) Sea trout of the North Esk. Aquacult Res 14:49-65

Qiu W, Chavarro J, Lazarus R, Rosner B, Ma J (2012) powerSurvEpi (v 0.06): Power and sample size calculation for survival analysis of epidemiological studies. Boston, MA. https://CRAN.R-project.org/package=powerSurvEpi

* Rao GMM (1968) Oxygen consumption of rainbow trout (Salmo gairdneri) in relation to activity and salinity. Can J Zool 46:781-786

Sahashi G, Morita K (2018) Adoption of alternative migratory tactics: a view from the ultimate mechanism and threshold trait changes in a salmonid fish. Oikos 127: 239-251

* Serra-Llinares RM, Bjørn PA, Finstad B, Nilsen R, Harbitz A, Berg M, Asplin L (2014) Salmon lice infection on wild salmonids in marine protected areas: an evaluation of the Norwegian 'National Salmon Fjords'. Aquacult Environ Interact 5:1-16

* Serra-Llinares RM, Bjørn PA, Finstad B, Nilsen R, Asplin L (2016) Nearby farms are a source of lice for wild salmonids: a reply to Jansen et al. (2016). Aquacult Environ Interact 8:351-356

* Serra-Llinares RM, Freitas C, Nilsen R, Elvik KMS and others (2018) Towards direct evidence of the effects of salmon lice (Lepeophtheirus salmonis Krøyer) on sea trout (Salmo trutta L.) in their natural habitat: proof of concept for a new combination of methods. Environ Biol Fishes 101:1677-1692

Shaw AK (2016) Drivers of animal migration and implications in changing environments. Evol Ecol 30:991-1007 
Shchepetkin AF, McWilliams JC (2005) The regional oceanic modeling system (ROMS): a split-explicit, free-surface, topography-following-coordinate oceanic model. Ocean Model 9:347-404

Shephard S, MacIntyre C, Gargan P (2016) Aquaculture and environmental drivers of salmon lice infestation and body condition in sea trout. Aquacult Environ Interact 8: 597-610

Simpfendorfer CA, Heupel MR, Hueter RE (2002) Estimation of short-term centers of activity from an array of omnidirectional hydrophones and its use in studying animal movements. Can J Fish Aquat Sci 59:23-32

Skaala Ø, Kålås S, Borgstrøm R (2014) Evidence of salmon lice-induced mortality of anadromous brown trout (Salmo trutta) in the Hardangerfjord, Norway. Mar Biol Res 10:279-288

Stien A, Bjørn PA, Heuch PA, Elston DA (2005) Population dynamics of salmon lice Lepeophtheirus salmonis on Atlantic salmon and sea trout. Mar Ecol Prog Ser 290: 263-275

Taranger GL, Karlsen Ø, Bannister RJ, Glover KA and others (2015) Risk assessment of the environmental impact of Norwegian Atlantic salmon farming. ICES J Mar Sci 72: 997-1021

Therneau T (2014) A package for survival analysis in S. $\mathrm{R}$ package version 2.37-7, https://CRAN.R-project.org/ package=survival

Thorstad EB, Todd CD, Uglem I, Bjørn PA and others (2015) Effects of salmon lice Lepeophtheirus salmonis on wild sea trout Salmo trutta-a literature review. Aquacult Environ Interact 7:91-113

Editorial responsibility: Jana Davis, Annapolis, Maryland, USA
Thorstad EB, Todd CD, Uglem I, Bjørn PA and others (2016) Marine life of the sea trout. Mar Biol 163:47

Tjomsland T, Kroglund F (2010) Modellering av strøm og saltholdighet i Sandnesfjorden ved Risør. Rapport 6049-2010. NIVA, Grimstad (in Norwegian with English summary)

* Tully O, Poole W, Whelan K (1993a) Infestation parameters for Lepeophtheirus salmonis (Kroyer)(Copepoda: Caligidae) parasitic on sea trout, Salmo trutta L., off the west coast of Ireland during 1990 and 1991. Aquacult Res 24:545-555

Tully O, Poole W, Whelan K, Merigoux S (1993b) Parameters and possible causes of epizootics of Lepeophtheirus salmonis (Krøyer) infesting sea trout (Salmo trutta L.) off the west coast of Ireland. In: Boxshall GA, Defaye D (eds) Pathogens of wild and farmed fish: sea lice. Ellis Horwood, London, p 202-213

*Vollset KW, Barlaup BT, Skoglund H, Normann ES, Skilbrei OT (2014) Salmon lice increase the age of returning Atlantic salmon. Biol Lett 10:20130896

Wells A, Grierson CE, MacKenzie M, Russon IJ and others (2006) Physiological effects of simultaneous, abrupt seawater entry and sea lice (Lepeophtheirus salmonis) infestation of wild, sea-run brown trout (Salmo trutta) smolts. Can J Fish Aquat Sci 63:2809-2821

Wells A, Grierson CE, Marshall L, MacKenzie M and others (2007) Physiological consequences of 'premature freshwater return' for wild sea-run brown trout (Salmo trutta) postsmolts infested with sea lice (Lepeophtheirus salmonis). Can J Fish Aquat Sci 64:1360-1369

Wright DW, Oppedal F, Dempster T (2016) Early stage sea lice recruits on Atlantic salmon are freshwater sensitive. J Fish Dis 39:1179-1186

Submitted: June 26, 2019; Accepted: November 13, 2019

Proofs received from author(s): January 20, 2020 